\title{
Ion channels in control of pancreatic stellate cell migration
}

\author{
Hannah Storck ${ }^{1}$, Benedikt Hild ${ }^{1}$, Sandra Schimmelpfennig ${ }^{1}$, Sarah Sargin ${ }^{1}$, Nikolaj \\ Nielsen $^{1}$, Angela Zaccagnino ${ }^{4}$, Thomas Budde ${ }^{2}$, Ivana Novak ${ }^{3}$, Holger Kalthoff ${ }^{4}$, \\ Albrecht Schwab ${ }^{1}$ \\ ${ }^{1}$ Institut für Physiologie II, 48149 Münster, Gemany \\ ${ }^{2}$ Institut für Physiologie I, 48149 Münster, Gemany \\ ${ }^{3}$ Section for Cell Biology and Physiology, Department of Biology, University of Copenhagen, DK 2100 Copenhagen, Denmark \\ ${ }^{4}$ UKSH, Campus Kiel, Institut für Experimentelle Tumorforschung (IET), Sektion Molekulare Onkologie, D-24105 Kiel, \\ Germany
}

Correspondence to: Albrecht Schwab, email: aschwab@uni-muenster.de

Keywords: pancreatic stellate cell, migration, $K_{C a} 3.1$ channel, TRPC3 channel

Received: August 25, 2016

Accepted: November 07, 2016

Published: November 26, 2016

\section{ABSTRACT}

Pancreatic stellate cells (PSCs) play a critical role in the progression of pancreatic ductal adenocarcinoma (PDAC). Once activated, PSCs support proliferation and metastasis of carcinoma cells. PSCs even co-metastasise with carcinoma cells. This requires the ability of PSCs to migrate. In recent years, it has been established that almost all "hallmarks of cancer" such as proliferation or migration/invasion also rely on the expression and function of ion channels. So far, there is only very limited information about the function of ion channels in PSCs. Yet, there is growing evidence that ion channels in stromal cells also contribute to tumor progression. Here we investigated the function of $K_{\mathrm{ca}} 3.1$ channels in PSCs. $K_{\mathrm{ca}} 3.1$ channels are also found in many tumor cells of different origin. We revealed the functional expression of $K_{\mathrm{ca}} 3.1$ channels by means of Western blot, immunofluorescence and patch clamp analysis. The impact of $\mathrm{K}_{\mathrm{Ca}} 3.1$ channel activity on PSC function was determined with live-cell imaging and by measuring the intracellular $\mathrm{Ca}^{+}$concentration $\left(\left[\mathrm{Ca}^{2+}\right]_{i}\right)$. $\mathrm{K}_{\mathrm{ca}} 3.1$ channel blockade or knockout prevents the stimulation of PSC migration and chemotaxis by reducing the $\left[\mathrm{Ca}^{2+}\right]_{\mathrm{i}}$ and calpain activity. $\mathrm{K}_{\mathrm{Ca}} 3.1$ channels functionally cooperate with TRPC 3 channels that are upregulated in PDAC stroma. Knockdown of TRPC3 channels largely abolishes the impact of $K_{\mathrm{ca}} 3.1$ channels on PSC migration. In summary, our results clearly show that ion channels are crucial players in PSC physiology and pathophysiology.

\section{INTRODUCTION}

Pancreatic stellate cells (PSCs) constitute a small fraction of cells in the periacinar space that are normally quiescent. Their function in a healthy pancreas has begun to be unravelled only recently. Roles in matrix turnover, regulation of exocrine secretion, immune functions, as well as progenitor functions have been shown [1-3]. It is well established that activated PSCs as well as infiltrating myeloid cells and lymphocytes are of great importance in pancreatic pathologies such as chronic (alcoholic) pancreatitis or pancreatic ductal adenocarcinoma (PDAC). PSCs are the predominant mesenchymal cells within the
PDAC stroma [4]. They are activated by growth factors and cytokines (e.g. PDGF and TGF- $\beta$, IL8 and TNF-a) produced by tumor cells or by themselves (autocrine stimulation [5, 6]). Activated PSCs have an enhanced migratory activity, and in turn, secrete growth factors and cytokines. In PDAC this is the basis for mutual paracrine stimulation of tumor and stroma cells that leads, in a positive feedback cycle, to excessive matrix production (desmoplasia) and creates a hypoxic microenvironment conducive to invasive tumor growth and metastasis $[7,8]$. Thus, the characteristic tumor stroma of PDAC and the mutual interaction of all its components play important roles in many aspects of tumor progression and in 
preventing efficient therapy. Accordingly, activated PSCs are in part responsible for the high mortality of PDAC patients whose 5-year survival rate is less than 5\% [9]. However, there is some controversy with respect to this issue, since myofibroblasts have recently been shown to protect the host from the tumor $[10,11]$.

So far, there is limited knowledge on the function and expression of ion channels in PDAC [12-17]. Based on the critical role of ion channels in other tumors [18], it is reasonable to predict that they are important drivers of PDAC progression as well. We assume that this also applies for ion channels in PSCs. However, so far the role of ion channels in PSC physiology and pathophysiology is rather unexplored. There are only very few studies addressing this topic [19-22] some of which were performed on the closely related hepatic stellate cells [23, 24]. Yet, in analogy to other cell types of the tumor stroma it is very likely that altered ion channel expression and function in stimulated PSCs contribute to processes that are critical for PDAC progression such as cell migration and invasion, growth factor signaling, or proliferation and apoptosis [25]. In the present study we investigated the role of ion channels in PSC migration. Migration of PSCs has to be seen against the background that PSCs are also found in distant PDAC metastases [2] so that migration of PSCs is one of the prerequisites of co-metastases [25]. One of the best studied ion channels involved in cell migration is a $\mathrm{Ca}^{2+}$ sensitive $\mathrm{K}^{+}$channel of intermediate conductance, $\mathrm{K}_{\mathrm{Ca}} 3.1$, which is expressed in almost all migrating cells [26-28]. Here we show that $\mathrm{K}_{\mathrm{Ca}} 3.1$ channels are also expressed in PSCs and contribute in cooperation with TRPC3 channels to their migratory activity.

\section{RESULTS}

\section{Functional $\mathrm{K}_{\mathrm{Ca}} 3.1$ channel expression in RLT- PSC cells}

Western blot analysis revealed that $\mathrm{K}_{\mathrm{Ca}} 3.1$ channels are expressed in RLT-PSCs. Incubation of RLT-PSCs in conditioned PDAC cell medium does not increase $\mathrm{K}_{\mathrm{Ca}} 3.1$ expression, which is consistent with the analysis of published micorarrays (see below). Immunofluorescence staining yielded the typical punctate staining of the channel protein (Figure 1A). A similar staining pattern is also observed in primary cultures of murine PSCs (Figure 1B). $\mathrm{K}_{\mathrm{Ca}} 3.1$ staining is absent in PSCs isolated from $\mathrm{K}_{\mathrm{Ca}} 3.1^{-/-}$mice (Figure 1C). The final proof for the expression of functional $\mathrm{K}_{\mathrm{Ca}} 3.1$ channel proteins in the plasma membrane was obtained from patch clamp experiments. Using a $\mathrm{KCl}$ containing pipette solution we recorded an outwardly rectifying whole-cell current with the typical pharmacological properties of $\mathrm{K}_{\mathrm{Ca}} 3.1$ channels ( $n=8$; see Figure 1D [29]). Mean current density rises from $4.8 \pm 1.0 \mathrm{pA} / \mathrm{pF}$ under control conditions to $24.9 \pm 2.0 \mathrm{pA} / \mathrm{pF}$ in the presence of $50 \mu \mathrm{mol} / 1 \mathrm{l}-\mathrm{EBIO}$.
Clotrimazole $(1 \mu \mathrm{mol} / \mathrm{l})$ reduces current density to $9.3 \pm$ $1.1 \mathrm{pA} / \mathrm{pF}$ in the continued presence of 1-EBIO (Figure $1 \mathrm{E} ; n=9)$. The respective reversal potentials are -41.8 $\pm 0.7 \mathrm{mV}$ (control), $-65.2 \pm 3.0 \mathrm{mV}$ (1-EBIO), and -51.7 $\pm 2.4 \mathrm{mV}$ (1-EBIO and clotrimazole) (Figure 1F), which is consistent with the activation and subsequent (partial) inhibition of a $\mathrm{K}^{+}$current.

\section{Stimulation of migration of PSCs requires $\mathrm{K}_{\mathrm{Ca}} 3.1$ channels}

PSCs are stimulated in a paracrine way by neighboring PDAC cells. We mimicked this situation in vitro by exposing RLT-PSCs to the supernatant of different PDAC cell lines. While the supernatant of BxPC3 cells does not increase motility of RLT-PSCs, those from Panc-1 and Colo357 cells induce a marked activation of RLT-PSC migration. Panel A of Figure 2 shows the trajectories of individual RLT-PSCs without stimulation (top) and after stimulation with the supernatant of Panc-1 cells (middle) or Colo357 cells (bottom). The length of the trajectories of stimulated cells is much longer than under control conditions. This is particularly evident when RLT-PSCs are treated with supernatant of Colo357 cells. Panel B of Figure 2 depicts the trajectories of RLT-PSCs treated with the $\mathrm{K}_{\mathrm{Ca}} 3.1$ channel inhibitor TRAM-34 (10 $\mu \mathrm{mol} / 1)$. We used this high concentration since protein binding of TRAM-34 was found to be 98\% [30]. TRAM-34 efficiently prevents the stimulation of migration while it has only a minor effect on basal, unstimulated migration. The experiments are summarized in panel C. When compared with unstimulated cells, the supernatant of Colo357 cells more than doubles the speed and translocation $(0.45 \pm 0.04 \mu \mathrm{m} / \mathrm{min}$ and $48.8 \pm 10.2$ $\mu \mathrm{m}$ versus $0.98 \pm 0.09 \mu \mathrm{m} / \mathrm{min}$ and $110.7 \pm 16.1 \mu \mathrm{m})$. The stimulation is largely reversed by blocking $\mathrm{K}_{\mathrm{Ca}} 3.1$ channels with TRAM-34 (69.9 $\pm 10.1 \mu \mathrm{m})$. We also observed a stimulatory effect on migration depending on $\mathrm{K}_{\mathrm{Ca}} 3.1$ channel activity when RLT-PSCs were treated with PDGF (50 ng/ml) which is expressed by PDAC cells [6] (see Figure 2D, 2E). It is noteworthy that under all conditions $\mathrm{K}_{\mathrm{Ca}} 3.1$ channel blockade caused a decrease of the cellular directionality by $\sim 20 \%$.

To rule out that the observed effects of $\mathrm{K}_{\mathrm{Ca}} 3.1$ channels on migration of RLT-PSCs are a consequence of their immortalization we performed additional experiments with primary murine PSCs. Having seen an effect of $\mathrm{K}_{\mathrm{Ca}} 3.1$ channel blockade on the directionality we now studied the effect of TRAM-34 or of $\mathrm{K}_{\mathrm{Ca}} 3.1$ channel knock-out on chemotaxis of murine PSCs towards PDGF. Murine PSCs migrate more slowly than RLT-PSCs $(\sim 8.4$ $\mu \mathrm{m} / \mathrm{h}$ versus $\sim 16 \mu \mathrm{m} / \mathrm{h}$ ). PDGF, however, also leads to an acceleration of murine wtPSCs which then cover $\sim 10.5$ $\mu \mathrm{m} / \mathrm{h}$. Murine wtPSCs chemotax efficiently in a gradient of PDGF as indicated by the asymmetric trajectories depicted in Figure 3A and 3C. The average chemotactic 
index is $0.33 \pm 0.03$ in a gradient of PDGF with peak values of up to $0.42 \pm 0.03$ during the second half of the experiment (Figure $3 \mathrm{E}$ and $3 \mathrm{~F}$ ). $\mathrm{K}_{\mathrm{Ca}} 3.1$ channel blockade with $10 \mu \mathrm{mol} / 1$ TRAM-34 slows down PDGF-stimulated murine PSCs to $\sim 8.8 \mu \mathrm{m} / \mathrm{h}$ and causes a marked delay in the onset as well as an attenuation of chemotaxis (chemotaxis index $0.23 \pm 0.03$ with peak values of $0.33 \pm$ 0.04 during the second half of the experiment). The role of $\mathrm{K}_{\mathrm{Ca}} 3.1$ channels in murine PSC migration and chemotaxis is further confirmed by studying $\mathrm{K}_{\mathrm{Ca}} 3.1^{-/-}$PSCs (Figure $3 \mathrm{E})$. Both, the rate of migration $(\sim 5.8 \mu \mathrm{m} / \mathrm{h}$ versus $\sim 13.5$ $\mu \mathrm{m} / \mathrm{h})$ and the chemotaxis index $(0.15 \pm 0.05$ versus $0.3 \pm$ 0.3 ; Figure $3 \mathrm{~F}$ ) are markedly lower in $\mathrm{K}_{\mathrm{Ca}} 3.1^{-/-}$PSCs than in cells from the respective wildtype littermates.

\section{Impact of $\mathrm{K}_{\mathrm{Ca}} 3.1$ channels on $\left[\mathrm{Ca}^{2+}\right]_{\mathrm{i}}$ of RLT- PSCs}

We next determined mechanisms by which $\mathrm{K}_{\mathrm{Ca}} 3.1$ channel blockade impairs migration of PSCs. We first tested whether the pretreatment of RLT-PSCs with the supernatant of Colo357 cells induced an increase of the $\left[\mathrm{Ca}^{2+}\right]_{\mathrm{i}}$. As shown in Figure $4 \mathrm{~A}$ the basal $\left[\mathrm{Ca}^{2+}\right]_{\mathrm{i}}$ is higher in pretreated cells. The $\left[\mathrm{Ca}^{2+}\right]_{i}$ of unstimulated cells amounts to $90.2 \pm 6.1 \mathrm{nmol} / 1$. It rises to $148.3 \pm 21.4 \mathrm{nmol} / 1$ when cells are exposed for three hours to the Colo357 cell supernatant. Application of the $\mathrm{K}_{\mathrm{Ca}} 3.1$ channel blocker TRAM-34 $(10 \mu \mathrm{mol} / \mathrm{l})$ induces a decrease of $\left[\mathrm{Ca}^{2+}\right]_{\mathrm{i}}$ to $95.6 \pm 10.2 \mathrm{nmol} / \mathrm{l}$. The corresponding values for RLTPSCs stimulated with the supernatant of Panc- 1 cells are $109.1 \pm 9.8 \mathrm{nmol} / 1$ and $87.0 \pm 8.2 \mathrm{nmol} / 1$, respectively. In unstimulated cells TRAM-34 does not induce a change of $\left[\mathrm{Ca}^{2+}\right]_{\mathrm{i}}$ which remains stable at $87.7 \pm 6.0 \mathrm{nmol} / 1$.

In another set of experiments we also studied the effect of depolarizing the cell membrane potential with a Ringer's solution containing $50 \mathrm{mmol} / 1 \mathrm{KCl}$. In RLTPSCs stimulated with Colo357 supernatant $\left[\mathrm{Ca}^{2+}\right]_{\mathrm{i}}$ falls to a similar extent $(-34.1 \pm 6.7 \mathrm{nmol} / \mathrm{l})$ as with $500 \mathrm{nmol} / \mathrm{l}$ TRAM-34 (-27.8 $\pm 5.5 \mathrm{nmol} / \mathrm{l}$; Figure 4B). Collectively, these experiments suggest that $\mathrm{K}_{\mathrm{Ca}} 3.1$ channels regulate
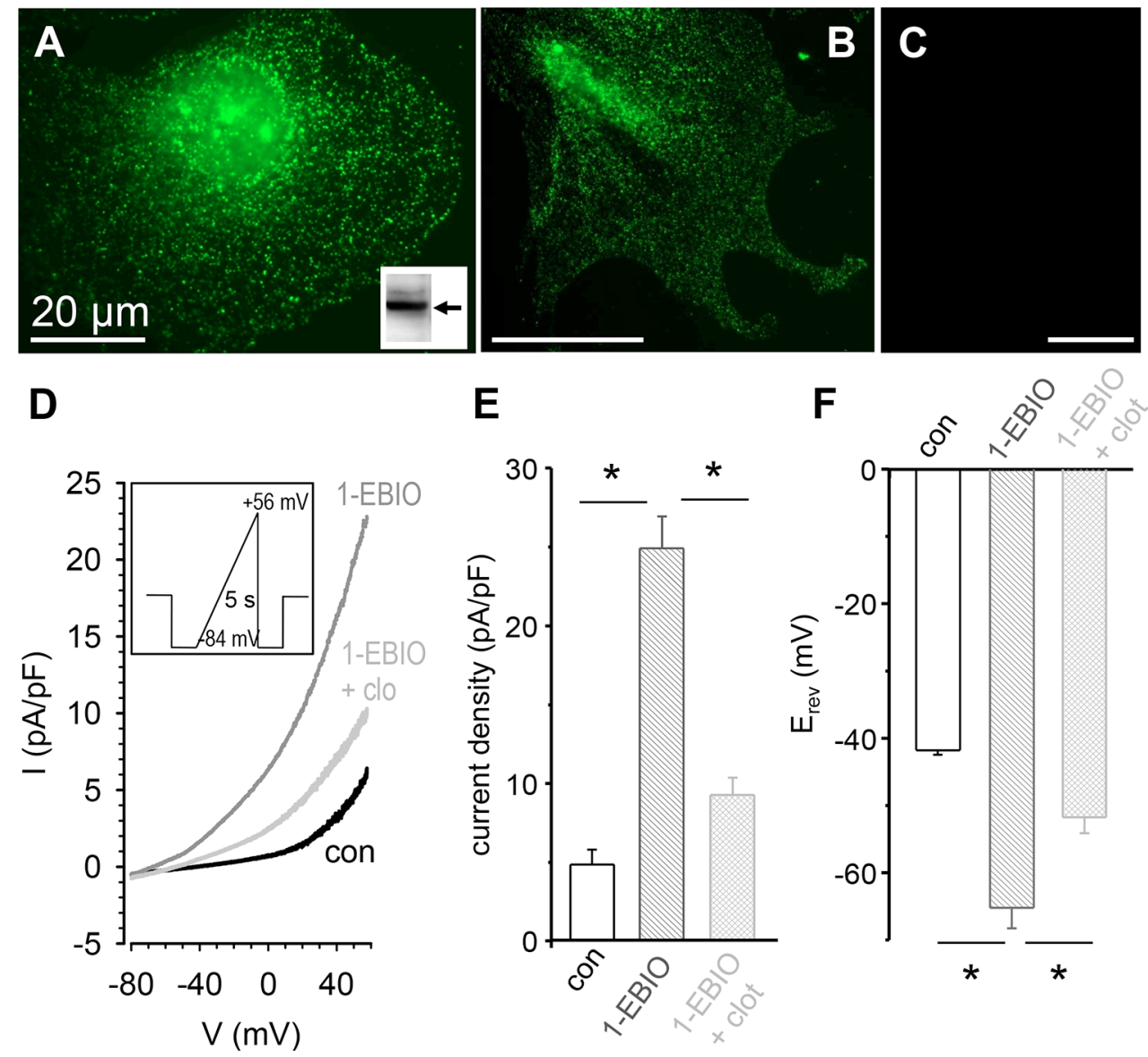

Figure 1: Expression of KCa3.1 in RLT-PSCs. (A, B) Immunofluorescence and Western blot. Staining of $\mathrm{K}_{\mathrm{Ca}} 3.1$ channels in RLTPSCs (A) and primary murine PSCs (B) by indirect immunofluorescence reveals the typical punctate pattern. Inset: Western blot analysis yields a band of the expected size $(\sim 50 \mathrm{kD})$. (C) $\mathrm{K}_{\mathrm{Ca}} 3.1$ channels are not detected in PSCs from $\mathrm{K}_{\mathrm{Ca}} 3.1^{-/-}$mice. (D) Original recording of a patch clamp experiment in the whole-cell configuration. The holding potential was $-40 \mathrm{mV}$. We applied a voltage ramp of $5 \mathrm{~s}$ duration from $-84 \mathrm{mV}+56 \mathrm{mV}$. The $\mathrm{K}_{\mathrm{Ca}} 3.1$ channel activator 1-EBIO $(50 \mu \mathrm{mol} / \mathrm{l})$ produced a large outward current which was inhibited by clotrimazole $(1 \mu \mathrm{mol} / \mathrm{l})$. (E, F) Summary of the patch clamp experiments. The current densities $(\mathrm{pA} / \mathrm{pF})$ are plotted in E., and F. depicts the reversal potentials $(n=9)$. * denotes $p \leq 0.05$. 


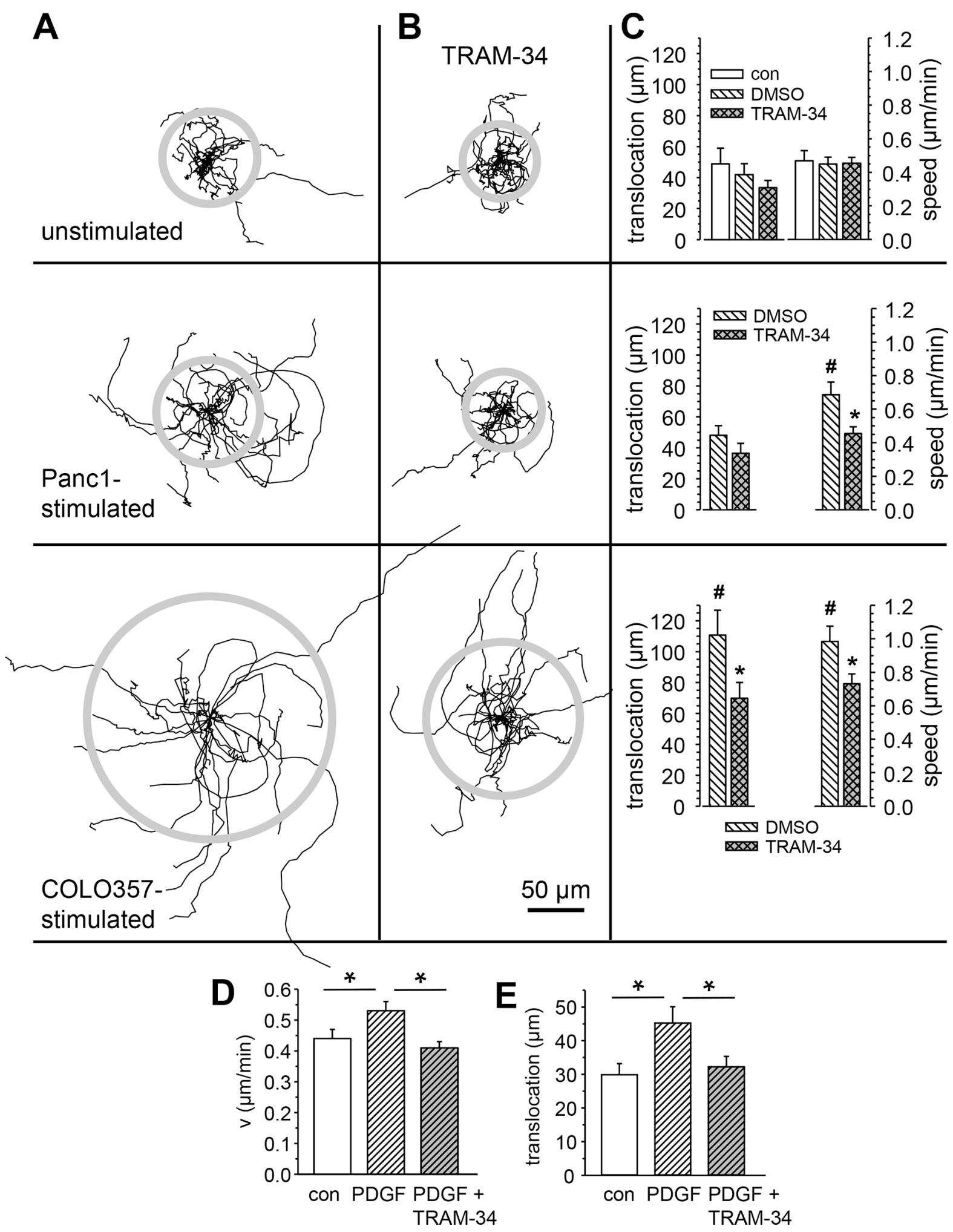

Figure 2: Stimulation of RLT-PSC migration by conditioned PDAC cell medium and PDGF requires $\mathrm{K}_{\mathrm{Ca}} 3.1$ channel activity. (A, B) Trajectories of migrating RLT-PSCs normalized to common starting points in the absence and presence of the $\mathrm{K}_{\mathrm{Ca}} 3.1$ channel blocker TRAM-34 (10 $\mu \mathrm{mol} / \mathrm{l})$. The radii of the grey circles depict the mean translocation of each cell population. (C) Summary of the migration experiments shown in A and B. \# denotes statistically significant difference from unstimulated cells, and * indicates a significant effect of $\mathrm{K}_{\mathrm{Ca}} 3.1$ channel blockade with TRAM-34 ( $p<0.05 ; n=20$ cells from $\mathrm{N} \geq 3$ experiments). (D, E) PDGF stimulates migration of RLT-PSCs in a $\mathrm{K}_{\mathrm{Ca}} 3.1$ channel dependent manner. D. Speed of migration. E. Translocation. * denotes statistically significant difference from unstimulated cells. $n \geq 47$ cells from $N \geq 5$ experiments. 
wt PSC: PDGF

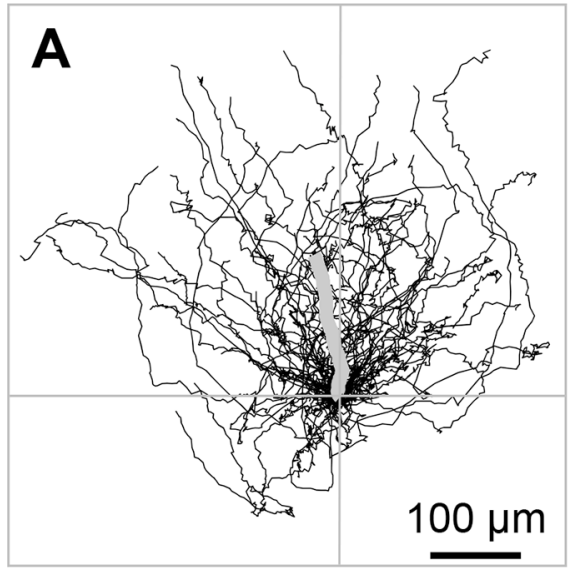

wt PSC: PDGF

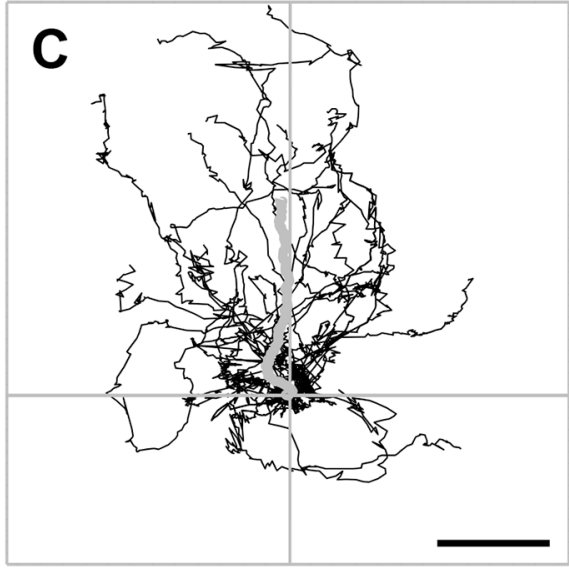

wt PSC: PDGF + TRAM-34

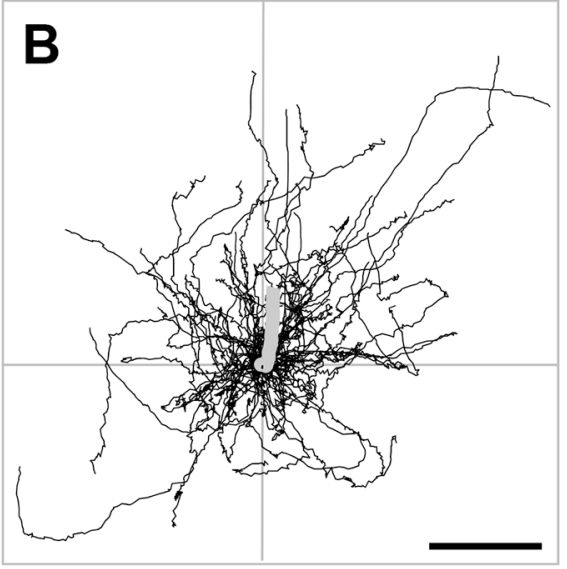

$\mathrm{K}_{\mathrm{Ca}} 3.1^{-1-} \mathrm{PSC}:$ PDGF
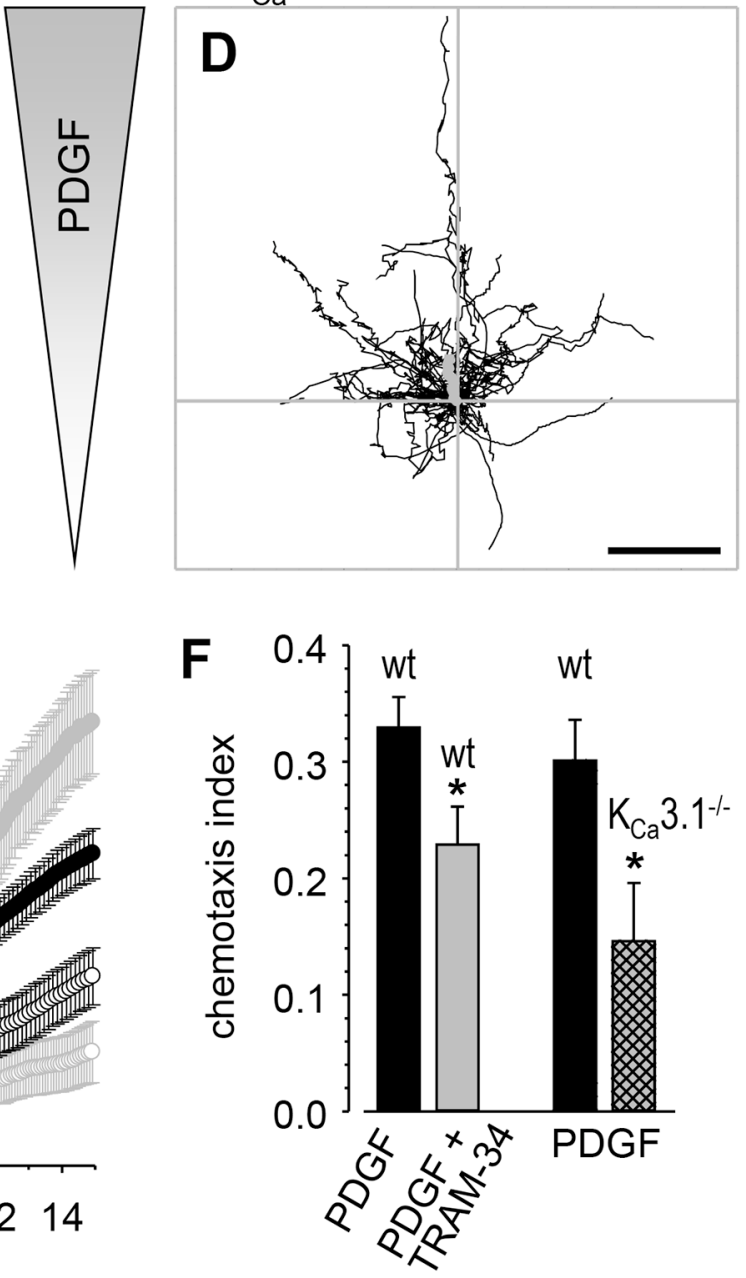

Figure 3: Chemotaxis of primary murine stellate cells towards PDGF is attenuated by $\mathrm{K}_{\mathrm{Ca}} 3.1$ channel inhibition. (A-D) Trajectories of individual PSCs normalized to common starting points. The grey shaded triangle indicates the chemotactic PDGF gradient with an increasing concentration towards the top. The bold grey lines represent the average movement of the entire cell populations. (A, B) PSCs from wt mice in the absence and presence of the $\mathrm{K}_{\mathrm{Ca}} 3.1$ channel blocker TRAM-34. (C, D) PSCs from wt mice and their $\mathrm{K}_{\mathrm{Ca}} 3.1^{-/-}$ littermates. (E) Net movement into the direction of the chemotactic gradient. $\mathrm{K}_{\mathrm{Ca}} 3.1$ channel blockade and $\mathrm{K}_{\mathrm{Ca}} 3.1$ knock-out lead to a delay and an attenuation of the chemotactic movement. (F) Summary of the chemotactic indices of the experiments shown in (A-D) The left bars compare the mean chemotactic index of wt PSCs in the absence and presence of the $\mathrm{K}_{\mathrm{Ca}} 3.1$ channel inhibitor TRAM- 34 . The right columns summarize the experiments with $\mathrm{K}_{\mathrm{Ca}} 3 \cdot 1^{-/}$PSCs compared with the respective wt littermates. $n=22-43$ cells from $N=3-4$ mice. 
$\left[\mathrm{Ca}^{2+}\right]_{i}$ of RLT-PSCs by keeping the cell membrane potential at a hyperpolarized value. These data are consistent with an earlier study proposing the absence of voltage-gated $\mathrm{Ca}^{2+}$ channels in PSCs [31].

\section{$K_{\mathrm{Ca}} 3.1$ channel blockade reduces calpain activity in RLT-PSCs}

$\mathrm{K}_{\mathrm{Ca}} 3.1$ channel blockade induced a migratory phenotype suggestive of impaired detachment. Such an example is shown in Figure 4C. Here we superimposed all 37 images of a migration experiment. Four cell processes are clearly visible. The cell center is somewhat out of focus indicating that the cell body moved back and forth, whereas the peripheral processes remained attached to the substratum. Accordingly, the number of lamellipodia rises when PDGFstimulated RLT-PSCs are treated with the $\mathrm{K}_{\mathrm{Ca}} 3.1$ channel blocker TRAM-34 $(4.1 \pm 1.0$ versus $6.5 \pm 1.0)$.

One of the $\mathrm{Ca}^{2+}$-dependent regulators of focal adhesion turnover is calpain. We therefore tested whether the decrease of the $\left[\mathrm{Ca}^{2+}\right]_{\mathrm{i}}$ following $\mathrm{K}_{\mathrm{Ca}} 3.1$ channel blockade is accompanied by decreased calpain activity. The results of these experiments are shown in Figure 4D-4F. Using the fluorescent calpain substrate, CMAC, t-BOCLeu-Met, we found that calpain activity is reduced after treatment with the $\mathrm{K}_{\mathrm{Ca}} 3.1$ blocker TRAM-34 by $230 \%$.

\section{TRPC3 channels provide $K_{\mathrm{Ca}} 3.1$ channels with $\mathrm{Ca}^{2+}$}

Data mining of published microarray analyses of microdissected patient tissue samples revealed that TRPC3 channels are upregulated in the stromal compartment of PDAC as compared to that of chronic pancreatitis (Figure $5 \mathrm{~A}$ ). In contrast, $\mathrm{K}_{\mathrm{Ca}} 3.1$ channel expression is increased in PDAC cells but not in the tumor stroma (Figure 5B). We therefore tested whether TRPC3 channels are also expressed in RLT-PSCs. As shown by Western blot and immunofluorescence this is the case (Figure 5C). They have a similar distribution pattern as $\mathrm{K}_{\mathrm{Ca}} 3.1$ channels. We therefore reasoned whether TRPC3 channels might cooperate with $\mathrm{K}_{\mathrm{Ca}} 3.1$ channels in providing them with $\mathrm{Ca}^{2+}$ ions required for their activation. Such a coupling between TRPC 3 and $\mathrm{K}_{\mathrm{Ca}} 1.1$ channels has been found in podocytes [32]. To this end, we performed co-immunostaining of TRPC 3 and $\mathrm{K}_{\mathrm{Ca}} 3.1$ channels in RLT-PSCs. Figure $5 \mathrm{C}-5 \mathrm{E}$ reveal that approximately two thirds of TRPC 3 and $\mathrm{K}_{\mathrm{Ca}} 3.1$ channels are colocalized.

Next we evaluated their role in regulating the $\left[\mathrm{Ca}^{2+}\right]_{\mathrm{i}}$ of RLT-PSCs (see Figure 6A). $\left[\mathrm{Ca}^{2+}\right]_{\mathrm{i}}$ rises transiently to $\sim 550 \mathrm{nmol} / 1$ when stimulated with $50 \mathrm{ng} /$ $\mathrm{ml} \mathrm{PDGF}$. After $5 \mathrm{~min}\left[\mathrm{Ca}^{2+}\right]_{\mathrm{i}}$ has gradually fallen to $\sim 400$ nmol/1. Blocking $\mathrm{K}_{\mathrm{Ca}} 3.1$ channels with TRAM-34 in the continued presence of PDGF then leads to a decrease of
$\left[\mathrm{Ca}^{2+}\right]_{\mathrm{i}}$ to $\sim 250 \mathrm{nmol} / 1$. In siTRPC3-RLT-PSCs PDGF fails to elicit an increase of $\left[\mathrm{Ca}^{2+}\right]_{i}$.

\section{TRPC3 channels in PDGF-stimulated migration of RLT-PSCs}

We finally investigated whether TRPC3 channels are involved in the stimulation of RLT-PSC migration. We compared migration of PDGF-stimulated siTRPC3RLT-PSCs with that of control RLT-PSCs transfected with scrambled siRNA (Figure 6B and 6C). Control cells cover much larger distances $(127.8 \pm 16.2 \mu \mathrm{m})$ than siTRPC 3 cells $(57.7 \pm 5.6 \mu \mathrm{m})$. Blocking $\mathrm{K}_{\mathrm{Ca}} 3.1$ channels with TRAM-34 has no additional inhibitory effect, which is consistent with the notion that TRPC3 channels are functionally cooperating with $\mathrm{K}_{\mathrm{Ca}} 3.1$ channels by providing them with $\mathrm{Ca}^{2+}$.

\section{DISCUSSION}

This study is one of the first to explore the expression and function of ion channels in pancreatic stellate cells. The main findings of our study are that (i) pancreatic stellate cells functionally express $\mathrm{K}_{\mathrm{Ca}} 3.1$ channels whose activity (ii) is required for (directed) migration by (iii) regulating the $\left[\mathrm{Ca}^{2+}\right]_{\mathrm{i}}$ and thereby (iv) calpain activity. Finally, we showed that (v) the role of $\mathrm{K}_{\mathrm{Ca}} 3.1$ channels in cell migration depends on cooperation with TRPC3 channels which are upregulated in the stroma of PDAC tissue samples. Thus, $\mathrm{K}_{\mathrm{Ca}} 3.1$ channels are as expected closely linked to the intracellular $\mathrm{Ca}^{2+}$ homeostasis of PSCs.

So far, only few studies addressed the role of the $\left[\mathrm{Ca}^{2+}\right]_{i}$ in PSC function such as proliferation and the molecular nature of the channels involved in $\mathrm{Ca}^{2+}$ signaling $[20,31]$. They showed that (nuclear) $\mathrm{Ca}^{2+}$ signals are an important determinant of the proliferation of activated PSCs and that the " $\mathrm{Ca}^{2+}$ signature" of activated PSCs differs from that of quiescent PSCs [31]. However, several studies performed with hepatic stellate cells (HSCs), close "relatives" of PSCs, point to a causal relationship between intracellular $\mathrm{Ca}^{2+}$ signaling and pro-inflammatory as well as profibrotic events. Thus, norepinephrine-induced $\mathrm{Ca}^{2+}$ oscillations were linked to enhanced cytokine secretion (e.g. CCL5 (RANTES), IL-8) and thereby autocrine activation of HSCs [33]. Their activation by angiotensin II relies on more prolonged elevations of the $\left[\mathrm{Ca}^{2+}\right]_{\mathrm{i}}$ that in turn also involves the CD38-dependent production of the intracellular messengers cyclic ADP-ribose (cADPR) and nicotinic acid adenine dinucleotide phosphate (NAADP). This is a pathophysiologically relevant mechanism since $\mathrm{CD} 38^{-/-}$ mice are protected to some extent from liver fibrosis induced by bile duct ligation [34]. Finally, $\mathrm{K}_{\mathrm{Ca}} 3.1$ inhibition was shown to exert antifibrotic effects that could be related to an inhibition of TGF- $\beta$ signaling in hepatic stellate cells [24]. 

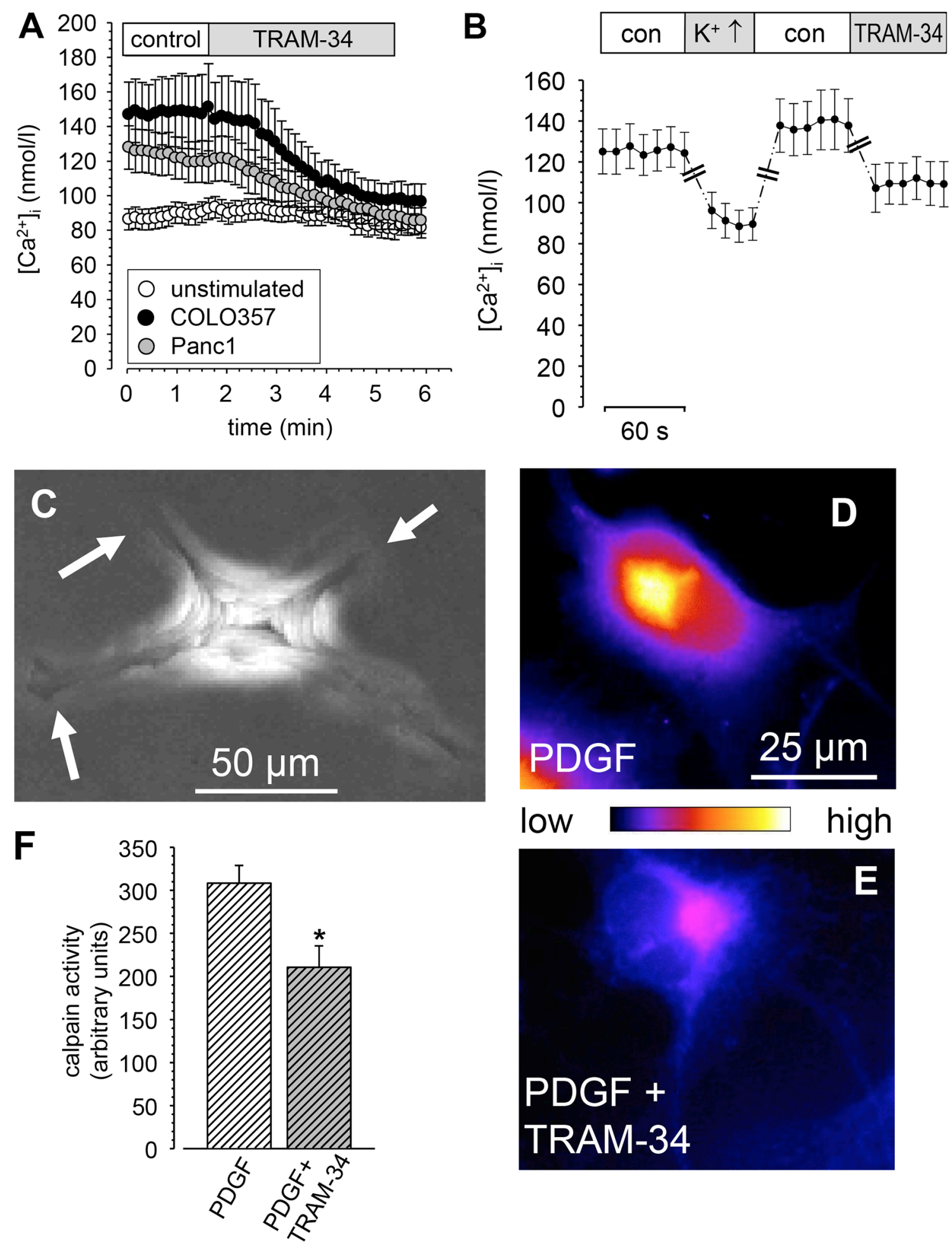

Figure 4: (A, B) Impact of $\mathrm{K}_{\mathrm{Ca}} 3.1$ channels on the $\left[\mathrm{Ca}^{2+}\right]_{\mathrm{i}}$ of RLT-PSCs stimulated with supernatant from Colo357 PDAC cells. (A) TRAM$34(10 \mu \mathrm{mol} / \mathrm{l})$ reduces the $\left[\mathrm{Ca}^{2+}\right]_{\mathrm{i}}$ of RLT-PSCs stimulated with the supernatants from COLO357 or Panc1 cells $(n=30$ cells from $N=6$ experiments each), but has no effect on untreated cells ( $n=30$ cells from $N=4$ experiments). B. Depolarizing the cell membrane potential with $50 \mathrm{mmol} / 1 \mathrm{KCl}$ has a similar impact on the $\left[\mathrm{Ca}^{2+}\right]_{\mathrm{i}}$ of activated RLT-PSCs as blocking $\mathrm{K}_{\mathrm{Ca}} 3.1$ channels with $500 \mathrm{nmol} / 1 \mathrm{TRAM}-34$ - $\left(n=14\right.$ cells from $N=5$ experiments; we only plotted the steady state values of the last $30-60 \mathrm{~s}$ of each condition). (C-F) Blocking $\mathrm{K}_{\mathrm{Ca}} 3.1$ channels impairs deadhesion of RLT-PSCs by reducing calpain activity. (C) "Z-stack" of 37 images acquired in 5 min intervals of a RLT-PSC treated with PDGF and TRAM-34. The lamellipodial processes (white arrows) are clearly visible indicating that they hardly moved throughout the experiment. (D, E) Fluorescence of the calpain substrate CMAC, t-BOC-Leu-Met in RLT-PSCs treated with PDGF (D) or PDGF and TRAM-34 (E, F) Summary of $N=7$ experiments with $\mathrm{n} \geq 30$ cells. 

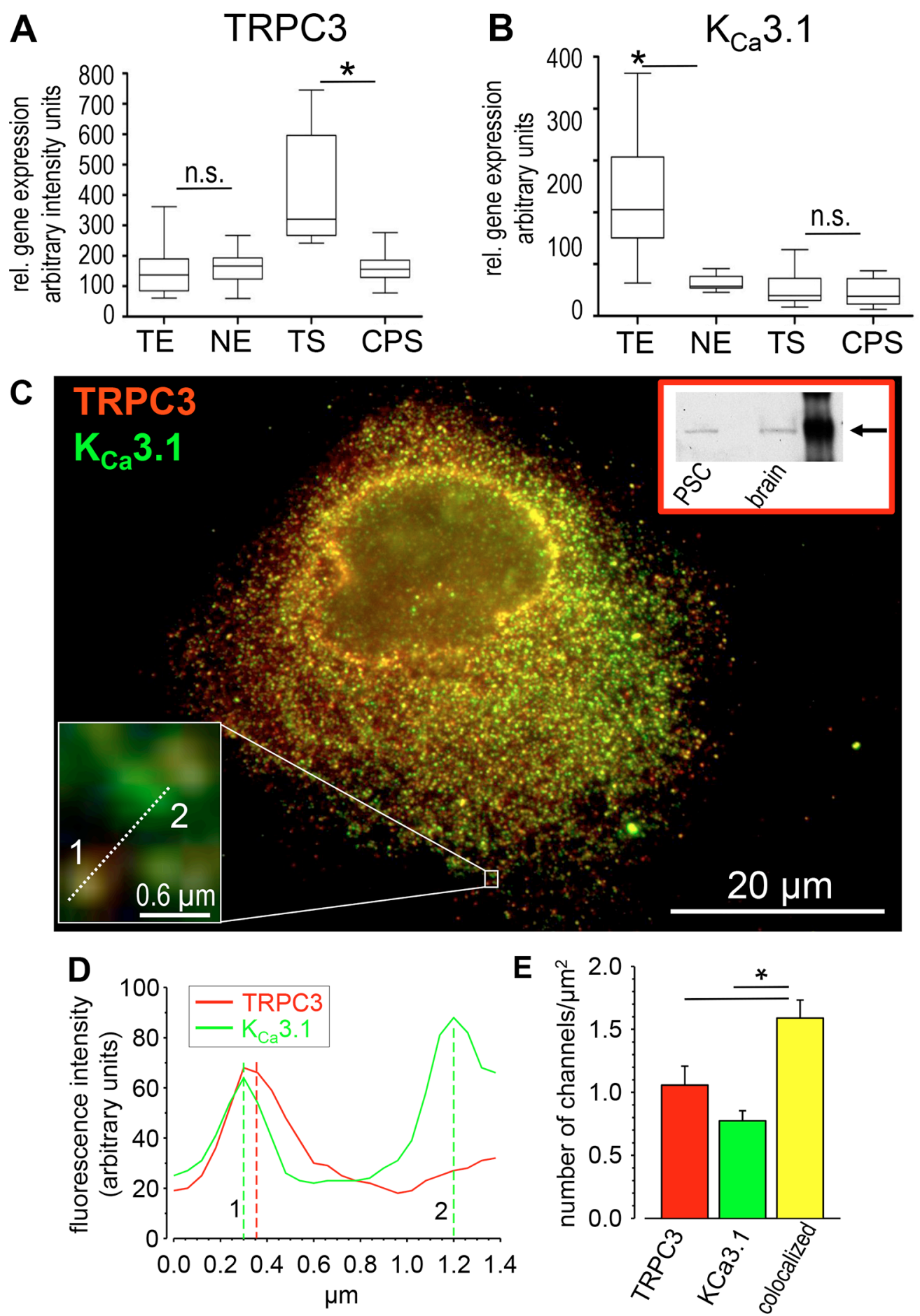

Figure 5: "Data mining" of published microarray analysis from microdissected freshly frozen tissue samples from PDAC $(n=14)$, normal pancreatic tissue $(n=11)$ and chronic pancreatitis specimens $(n=9)$ [56, 57] for TRPC3 (A) and $\mathrm{K}_{\mathrm{Ca}} 3.1$ channel (B) expression. TRPC3 expression is higher in tumor stroma (TS) than in chronic pancreatitis stroma (CPS), and that of $\mathrm{K}_{\mathrm{Ca}} 3.1$ channels is higher in tumor epithelium (TE) than in normal epithelial cells (NE). The Cel Files obtained from the Affymetrix MAS 5.0 software were loaded into dChip 1.3 (http://www.dchip.org), then normalized, and expression values as well as absolute calls were calculated using the PM/MM model. The analysis was carried out by using R-software, performing Wilcoxon-Mann-Whitney-Test and filtered by $p$-value $(<0.05)$ with Bonferroni's correction method. n.s.: not significant. $(\mathbf{C}-\mathbf{E})$ TRPC 3 und $\mathrm{K}_{\mathrm{Ca}} 3.1$ channels are colocalised in RLT-PSCs. The Western blot verifies the TRPC3 antibody specificity (inset in C). (C) Co-staining of TRPC3 channels (red) and $\mathrm{K}_{\mathrm{Ca}} 3.1$ channels (green). The inset (lower left) shows the boxed area in high magnification. (D) Intensity profile along the dotted line in the inset of (C). The fluorescent spot "1" consists of colocalized TRPC 3 and $\mathrm{K}_{\mathrm{Ca}} 3.1$ channels while " 2 " is a $\mathrm{K}_{\mathrm{Ca}} 3.1$ channel only. (E) Summary of the quantitative analysis. Approximately two thirds of the channel proteins are colocalized ( $n=30$ cells from $N=3$ experiments). 
A

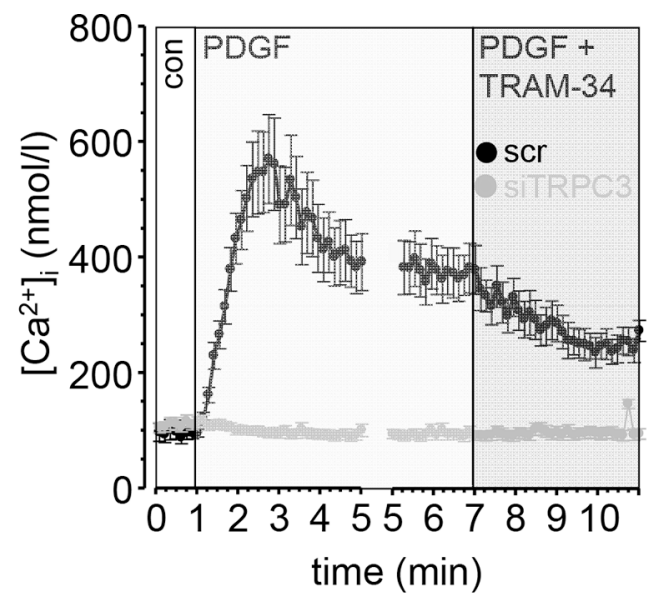

B
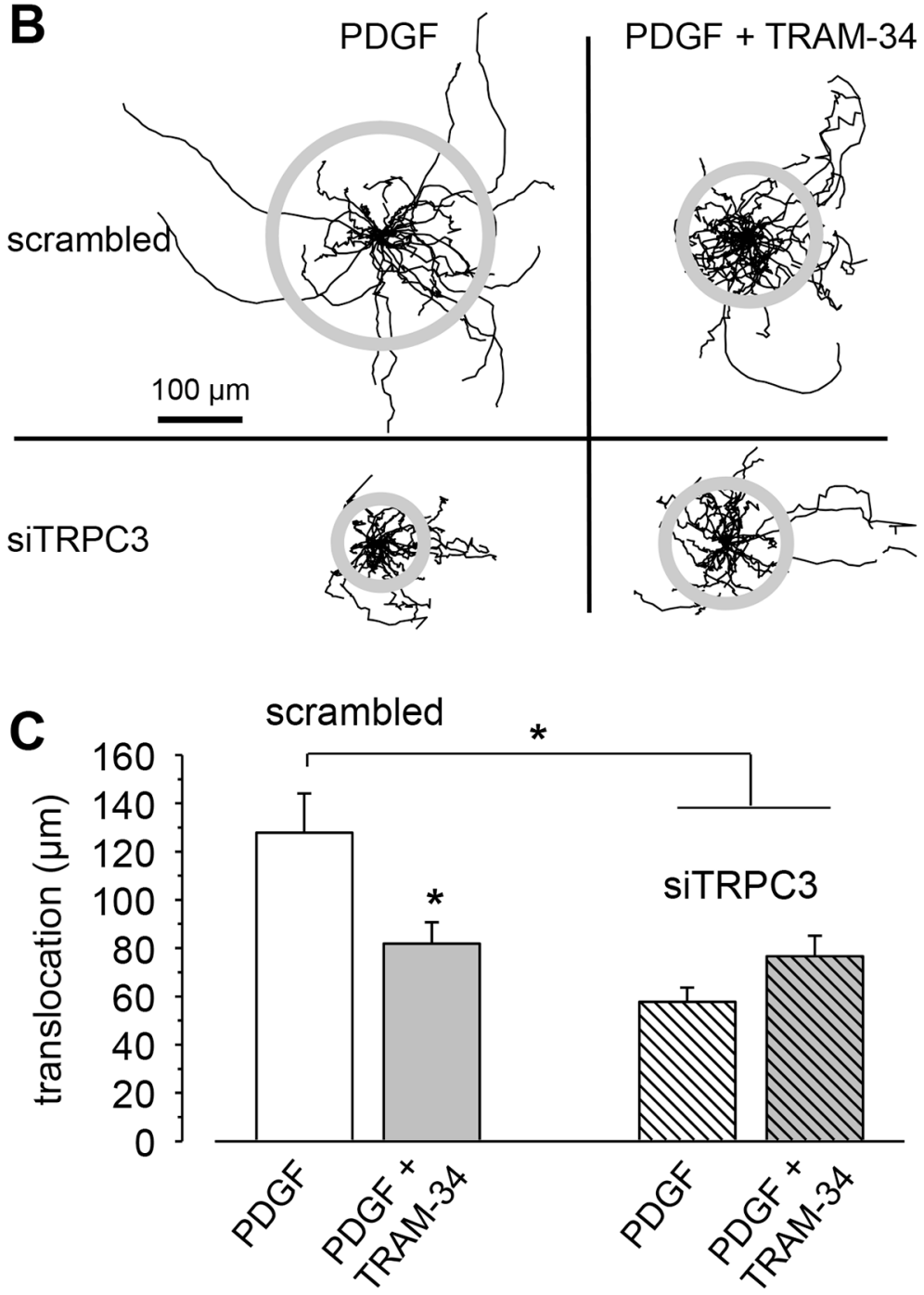

Figure 6: Impact of TRPC3 channels on the $\left[\mathrm{Ca}^{2+}\right]_{\mathrm{i}}$ and migration of RLT-PSCs. (A) PDGF induces a transient rise of the $\left[\mathrm{Ca}^{2+}\right]_{\mathrm{i}}$. Inhibition of $\mathrm{K}_{\mathrm{Ca}} 3.1$ channels with TRAM-34 leads to a reduction of the $\left[\mathrm{Ca}^{2+}\right]_{\mathrm{i}}(n=19$ from $N=3$ experiments). Knockdown of TRPC3 channels abrogates the increase of the $\left[\mathrm{Ca}^{2+}\right]_{\mathrm{i}}$ following stimulation with PDGF $(n=41$ from $N=3$ experiments). (B) Trajectories of RLT-PSCs transfected with scrambled siRNA or with siTRPC3 RNA. The trajectories are normalized to common starting points, and the radii of the grey circles represent the mean translocation of the cell populations. (C) Summary of the migration experiments. siTRPC3 transfection strongly reduced the translocation and makes the cells unresponsive to the $\mathrm{K}_{\mathrm{Ca}} 3.1$ channel blocker TRAM-34. $n \geq 31$ cells from $N \geq 3$ experiments. 
To our knowledge there are only very few studies showing a direct role of TRP channels in PSC function. TRPC1 channels are contributing to the pressure-induced activation of PSCs as revealed by a TRPC1-dependent stimulation of migration and $\mathrm{Ca}^{2+}$ influx [22]. TRPA1 channels are involved in the development of acute and chronic pancreatitis. Since they were rather found in pancreatic nerve fibers and dorsal root ganglia neurons innervating the pancreas than in PSCs, these channels were proposed to mediate a neurogenic inflammation of the pancreas $[35,36]$. Thus, in this model TRPA1 channels were thought to exert an indirect effect on pancreatic stellate cells. TRPV4 channels are functional in PSCs [19]. However, the fact that TRPV4 ${ }^{-/}$mice developed the same degree of (acute) pancreatitis as wildtype mice argues against a role of TRPV4 channels in this disease. Our findings could point to a role of TRPC 3 channels in pancreatitis. The attenuation of an acute pancreatitis in $\mathrm{TRPC}^{-/-}$animals was explained on the basis of an altered exocytotic protease secretion from acinar cells. In contrast to wt cells, exocytosis was maintained in TRPC $3^{-/}$acinar cells during supramaximal stimulation thereby preventing their pathological intracellular activation of proteases [32]. Since PSCs also become activated in an acute pancreatitis [37] our findings raise the possibility that a diminished activation of PSCs might have also contributed to the attenuated acute pancreatitis in TRPC $3^{-/-}$mice [38]. Along these lines it was also suggested that bradykinin-mediated $\mathrm{Ca}^{2+}$ signaling in PSCs could contribute to causing an ACE blocker-induced acute pancreatitis. These drugs inhibit bradykinin breakdown and could thereby activate PSCs by augmenting intracellular $\mathrm{Ca}^{2+}$ [39]. Collectively, these studies show that $\mathrm{Ca}^{2+}$ signaling plays an important role in stellate cell activation and hence qualifies the involved $\mathrm{Ca}^{2+}$ (sensitive) transport proteins as potential targets in stellate cell-directed antifibrotic and antiinflammatory therapies [40, 41]. However, so far there is no direct evidence for a role of ion channels in PSCs in the context of PDAC.

We found that $\mathrm{K}_{\mathrm{Ca}} 3.1$ and TRPC3 channels play important roles in stimulated migration of PSCs. Previously, we suggested that ion channels like $\mathrm{K}_{\mathrm{Ca}} 3.1$ are part of the migratory machinery by inducing localized changes of cell volume (reviewed in [27]). This hydrodynamic model of cell migration was confirmed by other groups [42-44]. Here, we report an additional mechanism by which $\mathrm{K}_{\mathrm{Ca}} 3.1$ channels can affect cell migration, namely by cooperating with TRPC3 channels. We found in PSCs that $\mathrm{K}_{\mathrm{Ca}} 3.1$ and TRPC3 channels are closely colocalized in the plasma membrane so that $\mathrm{Ca}^{2+}$ entering the cell via TRPC3 channels can activate neighboring $\mathrm{K}_{\mathrm{Ca}} 3.1$ channels. The ensuing hyperpolarization of the cell membrane potential increases or maintains the electrochemical driving force for $\mathrm{Ca}^{2+}$ entry. Conversely, a depolarization of the cell membrane potential by either blocking $\mathrm{K}_{\mathrm{Ca}} 3.1$ channels or by exposing the cell to $50 \mathrm{mmol} / \mathrm{K} \mathrm{KCl}$ leads to a decrease of the $\left[\mathrm{Ca}^{2+}\right]_{\mathrm{i}}$. An excessive positive feedback between $\mathrm{K}_{\mathrm{Ca}} 3.1$ activation induced by TRPC3-mediated $\mathrm{Ca}^{2+}$ influx may be prevented by the depolarizing impact of cation influx through TRPC 3 channels. Alternatively, it is conceivable that the increase of the $\left[\mathrm{Ca}^{2+}\right]_{\mathrm{i}}$ also activates other ion channels that depolarize the cell membrane potential such as TRPM4 channels or members of the ANO/TMEM16 family of $\mathrm{Cl}^{-}$channels $[45,46]$. However, because of the limited knowledge of the PSC transportome these two latter theories await experimental verification.

Led by the observation that $\mathrm{K}_{\mathrm{Ca}} 3.1$ channel blockade results in impaired deadhesion of PSCs we studied the role of the $\mathrm{Ca}^{2+}$ sensitive protease calpain which is a regulator of focal adhesions [47]. In $\mathrm{T}$ lymphocytes inhibition or knockdown of calpain induced a similar migratory phenotype as in PSCs treated with the $\mathrm{K}_{\mathrm{Ca}} 3.1$ channel blocker TRAM-34. The detachment of the trailing edge was disturbed [47]. So far we do not know whether the impaired directionality and chemotaxis following $\mathrm{K}_{\mathrm{Ca}} 3.1$ channel inhibition is also due to reduced calpain activity. In neutrophils calpain is involved in chemotaxis [48].

The cooperation between $\mathrm{K}_{\mathrm{Ca}} 3.1$ and TRPC3 channels is reminiscent to findings made in rat mesenteric artery endothelial cells where a similar functional interaction between TRPC3 and $\mathrm{K}_{\mathrm{Ca}} 3.1$ channels was found [49]. In migrating glioma cells TRPC1 and ClC-3 channels form a functional unit colocalized in caveolae. The role of ClC-3 channels in migration and chemotaxis depends on their supply with $\mathrm{Ca}^{2+}$ ions via TRPC1 channels [50]. Our results suggest that $\mathrm{K}_{\mathrm{Ca}} 3.1$ channels "utilize" $\mathrm{Ca}^{2+}$ ions entering the cell via TRPC 3 channels. In Figure 7 we present a model of the cooperation between $\mathrm{K}_{\mathrm{Ca}} 3.1$ and TRPC3 channels in PSC migration. Our findings help to better understand the physiology of PSCs which is important when viewed against the background of the controversial discussion on the role of PSCs in the progression of PDAC [10]. Our findings and those from other groups in hepatic stellate cells clearly show that ion channels are crucial players in PSC physiology and pathophysiology.

\section{MATERIALS AND METHODS}

\section{Cell culture}

Experiments were performed with a cell line of human pancreatic stellate cells, RLT-PSC [51] and three PDAC cell lines, BxPC3, Panc1, and Colo357. They were cultured in DMEM/F12 (RLT-PSC), RPMI 1640 (BxPC3), DMEM/RPMI 1640 (Colo357) and DMEM (Panc1) supplemented with $10 \%$ fetal calf serum (FCS, PAA Gold) at $37^{\circ} \mathrm{C}$ in a humidified air $/ 5 \% \mathrm{CO}_{2}$ atmosphere. PDAC cells were grown for three days 
to $80 \%$ confluence before conditioned medium was collected. It was cleared by sterile filtration and stored at $4^{\circ} \mathrm{C}$ before use.

\section{Isolation of primary murine pancreatic stellate cells}

Procedures were approved by the local authorities. The pancreata of 8 - 12 weeks old mice (C57BL/6; Charles River, Sulzfeld, Germany) or of $\mathrm{K}_{\mathrm{Ca}} 3.1^{-/-}$mice and the wt littermates (SV129 background) were removed after the animals were anaesthetized with isofluran and killed by cervical dislocation. The pancreas was isolated, cut into pieces and suspended in $3 \mathrm{ml}$ Grey's balanced salt solution (GBSS) containing $2.5 \mathrm{mg}$ collagenase P. After shaking for $30 \mathrm{~min}$ at $37^{\circ} \mathrm{C}$ the enzyme-containing solution was further diluted with GBSS and centrifuged. The pellet was resuspended in DMEM/F-12 medium containing $10 \% \mathrm{FCS}$ and $1 \%$ penicillin/streptomycin and plated in an FCS-coated cell culture dish. After two hours, the dish was washed with media. Since PSCs were the only cells that attached strongly [20] they could be easily isolated from the other non-adherent cells. Primary murine PSCs were used for the experiments after passaging them 1 to 2 times. The identity of primary murine PSCs was revealed by the disappearance of vitamin A droplets and the appearance of $\alpha$-smooth muscle actin and glial fibrillary acidic protein after a couple of days in culture.

\section{TRPC3 knockdown}

RLT-PSCs were grown over night in a $60 \mathrm{~mm}$ dish to $70 \%$ confluency. TRPC3 siRNA or control
siRNA (Invitrogen; $24 \mathrm{pmol} / 1$ each) were mixed with Opti-MEM (Invitrogen) and siRNA Lipofectamin (Invitrogen) according to the manufacturer's instructions. We used the following double-stranded oligos: sense: 5'-GCAGCAGCUCUUGACGAUCUGGUAU-3' antise nse: 5'-AUACCAGAUCGUCAAGAGCUGCUGC-3' [52]. Cells were used for experiments $48 \mathrm{~h}$ after transient transfection. In parallel to migration experiments and measurements of $\left[\mathrm{Ca}^{2+}\right]_{i}$ knockdown efficiency was confirmed by Western blot.

\section{Western blot}

RLT-PSCs grown to $80 \%$ confluency were washed before lysis in $50 \mathrm{mmol} / 1$ Tris- $\mathrm{HCl} \mathrm{pH} \mathrm{7.6,150} \mathrm{mmol/1}$ $\mathrm{NaCl}, 10 \mathrm{mmol} / \mathrm{l}$ Nonidet-P40, $3.5 \mathrm{mmol} / \mathrm{SDS}, 10 \%$ Na-deoxycholate, PhosSTOP (phosphatase inhibitor cocktail; Sigma) and cOmpleteMini (protease inhibitor cocktail; Sigma). Lysates were size-fractionated with SDS-PAGE (10\%) and blotted onto PVDF membranes. $\mathrm{K}_{\mathrm{Ca}} 3.1$ and TRPC3 channel proteins were labelled by successive incubation with the respective primary (rabbit

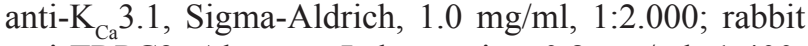
anti-TRPC3, Alomone Laboratories, $0.8 \mathrm{mg} / \mathrm{ml}, 1: 400$; mouse anti-actin, Sigma-Aldrich, $30.3 \mathrm{mg} / \mathrm{ml}, 1: 15.000$ ) and secondary antibodies (peroxidase conjugated goat anti-rabbit and anti-mouse, Sigma-Aldrich) followed by chemiluminescent detection (Pierce).

\section{Immunofluorescence}

Staining of $\mathrm{K}_{\mathrm{Ca}} 3.1$ channels was performed according to a protocol described previously [26]. Antibody

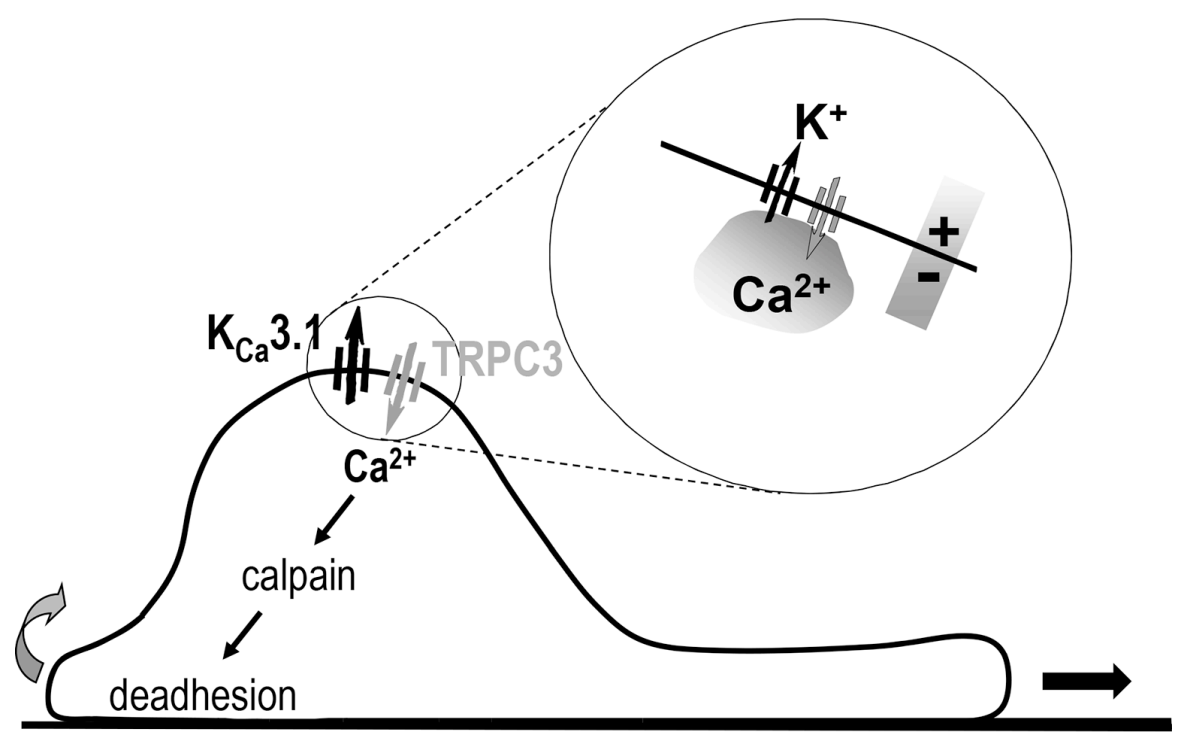

Figure 7: Summary scheme of how $K_{\mathrm{Ca}} 3.1$ and TRPC3 channels cooperate with each other in order to support migration. $\mathrm{K}_{\mathrm{Ca}} 3.1$ channels provide electrochemical driving force for $\mathrm{Ca}^{2+}$ entry via TRPC 3 channels. $\left[\mathrm{Ca}^{2+}\right]_{\mathrm{i}}$ in turn maintains activity of $\mathrm{K}_{\mathrm{Ca}} 3.1$ channels and, among others, activates calpain thereby promoting deadhesion of migrating stellate cells. 
Table 1: Composition of the extracellular matrices

\begin{tabular}{|l|c|}
\hline \multicolumn{2}{|c|}{ basement membrane matrix } \\
\hline RPMI $5 \times$ & $10.4 \mathrm{~g} / \mathrm{L}$ \\
\hline HEPES 5 & $10 \mathrm{mmol} / \mathrm{L}$ \\
\hline $\mathrm{NaOH}$ & $\sim 15 \mu \mathrm{L} 1 \mathrm{M} \mathrm{NaOH} \mathrm{per} 1 \mathrm{~mL}$ matrix solution $[58]$ \\
\hline laminin & $100 \mu \mathrm{g} / \mathrm{mL}$ \\
\hline fibronectin & $100 \mu \mathrm{g} / \mathrm{mL}$ \\
\hline collagen IV & $1 \mathrm{mg} / \mu \mathrm{L}$ \\
\hline $\mathrm{H}_{2} \mathrm{O}$ & $\mathrm{ad} 1 \mathrm{~mL}$ \\
\hline
\end{tabular}

titers were: primary rabbit anti- $\mathrm{K}_{\mathrm{Ca}} 3.1(1.0 \mathrm{mg} / \mathrm{ml})$, $1: 1.000,1 \mathrm{~h}$ and secondary goat anti-rabbit Alexa 488, 1 : $1.000,1 \mathrm{~h}$. After staining the cells were fixed again for 10 min in $3.5 \%$ paraformaldehyde.

For double-labelling of $\mathrm{K}_{\mathrm{Ca}} 3.1$ and TRPC 3 channels this protocol was modified because both primary antibodies were derived from rabbit. First, $\mathrm{K}_{\mathrm{Ca}} 3.1$ channels were stained as described above. Then the cells were fixed for $10 \mathrm{~min}$ in $3.5 \%$ paraformaldehyde before staining of TRPC 3 channels (TRPC 3 antibody concentration $0.8 \mathrm{mg} /$ $\mathrm{ml}, 1: 300)$ following the same protocol. We maximally increased the concentration of secondary antibody used to label $\mathrm{K}_{\mathrm{Ca}} 3.1$ channels (goat anti-rabbit Alexa 488, 1 : 200) without obtaining unspecific binding in the absence of the primary antibody. At the same time we maximally diluted the concentration of the secondary antibody used to mark TRPC 3 channels (goat anti-rabbit $\mathrm{Cy} 3,1: 800$ ) without diminishing the TRPC3 staining density. The high concentration of goat anti-rabbit Alexa 488 secondary antibody saturated all binding sites of primary anti- $\mathrm{K}_{\mathrm{Ca}} 3.1$ antibodies because the subsequent incubation with goat anti-rabbit Cy3 $(1: 800)$ did not produce any additional labelling.

We used an inverted microscope (Axiovert 200, Zeiss, Oberkochen, Germany) equipped with a digital camera (model 9.0, RT-SE-Spot, Visitron, Puchheim, Germany) and a 100x, 1.45 oil immersion objective for documentation. Data acquisition and analysis were performed with Metavue software (Visitron). The average density and colocalization of $\mathrm{K}_{\mathrm{Ca}} 3.1$ and TRPC 3 channels were determined in 6 areas $(3 \mu \mathrm{m} \times 3 \mu \mathrm{m})$ per cell. After correcting pixel shifts of superimposed images, we used the linescan tool in order to determine the optical center of the fluorescent spots. We assumed a colocalization between $\mathrm{K}_{\mathrm{Ca}} 3.1$ and TRPC 3 channels when the distance between their optical centers was less than 1 pixel (corresponding to $60 \mathrm{~nm}$ )[53].

\section{Patch clamp experiments}

Functional expression of $\mathrm{K}_{\mathrm{Ca}} 3.1$ channels was revealed by performing the patch clamp experiments using the whole cell configuration as described previously [29]. Experiments were performed at room temperature. The holding potential was $-40 \mathrm{mV}$ which is close to the cell membrane potential. Current amplitude was determined at the end of the depolarizing ramp protocol ( $5 \mathrm{~s} ;-84$ to $+56 \mathrm{mV}$ ). The extracellular solution was composed of (in mmol/l): $140 \mathrm{NaCl}, 5 \mathrm{KCl}, 10 \mathrm{HEPES}, 1 \mathrm{MgCl}_{2}$, and $1 \mathrm{CaCl}_{2}, \mathrm{pH} 7.4$ with $\mathrm{NaOH}$. The intracellular solution contained (in mmol/l): $140 \mathrm{KCl}, 10$ HEPES, 1.3 EGTA, $1.217 \mathrm{CaCl}_{2}$, and $1 \mathrm{MgCl}_{2}, \mathrm{pH} 7.4$ with $\mathrm{KOH}$. The calculated free $\mathrm{Ca}^{2+}$ concentration of the internal solution was $1 \mu \mathrm{mol} / \mathrm{l}$. Clotrimazole $(1 \mu \mathrm{mol} / \mathrm{l})$ and 1 -ethyl-2benzimidazolone (1-EBIO; $50 \mu \mathrm{mol} / \mathrm{l})$ were dissolved in DMSO, added to the extracellular solution, and applied for a time period of 2 and $10 \mathrm{~min}$, respectively. The final DMSO concentration was $<0.1 \%$. Recordings were analyzed using FitMaster and Origin 7.5 software.

\section{Migration experiments}

Migration of PSCs was quantified by means of livecell imaging as described previously [28]. Cells were seeded $3 \mathrm{~h}$ prior to the experiment into tissue culture flasks coated with a "basement membrane-like matrix" (Table 1). Image acquisition in $5 \mathrm{~min}$ intervals was controlled by HiPic or WASABI software (Hamamatsu). Migration was quantified as the movement of the cell center with time. We calculated the cell speed (in $\mu \mathrm{m} / \mathrm{min}$ ) as a three-point difference quotient and the translocation (in $\mu \mathrm{m}$ ) as the net distance covered within the experiment. The directionality was derived from the quotient of translocation and total path length.

\section{Chemotaxis experiments}

Chemotaxis experiments were performed in chemotaxis chambers (ibidi, Martinsried, Germany) coated for one hour with a "basement membrane"-like matrix (see Table 1). Cells were seeded in HEPESbuffered RPMI at a density of $8 \times 10^{5}$ cells $/ \mathrm{ml}$ and allowed to settle for three hours. Thereafter, the medium was exchanged and if applicable supplemented with $10 \mu \mathrm{mol} / 1$ TRAM-34. A chemotactic gradient was established according to the manufacturer's instructions by adding $17 \mu 1$ of PDGF-containing medium ( $400 \mathrm{ng} / \mathrm{ml}$ ) to one of the reservoirs of the chemotactic chamber. 
Chemotaxis was monitored by means of live-cell imaging for $\sim 16 \mathrm{~h}$ in $8 \mathrm{~min}$ intervals. The migratory behavior was analysed by manually tracking the cell center of each cell. Speed and translocation were calculated as described above. Chemotactic efficiency was determined as the chemotaxis index $(\mathrm{CI})$ which is the ratio of net movement into the direction of the gradient and the total distance covered during the course of the experiment. Movement towards increasing concentrations of PDGF is indicated by a positive $\mathrm{CI}$.

\section{Measurements of the intracellular $\mathrm{Ca}^{2+}$ concentration}

We determined the intracellular $\mathrm{Ca}^{2+}$ concentration $\left(\left[\mathrm{Ca}^{2+}\right]_{\mathrm{i}}\right)$ ratiometrically with the fluorescent $\mathrm{Ca}^{2+}$ indicator fura-2 as described previously [54]. Cells were plated on glass bottom dishes (Willco, Amsterdam, The Netherlands) coated with a basement membrane-like matrix and pretreated in the same way as for migration experiments. $3 \mathrm{~h}$ after plating, cells were loaded with fura2-AM (3 $\mu \mathrm{mol} / 1$, Calbiochem) for $20 \mathrm{~min}$ at $37^{\circ} \mathrm{C}$ in the respective culture medium. Then the cells were transferred to the stage of an inverted microscope (Axiovert 200, Zeiss) and continuously superfused with prewarmed $\left(37^{\circ} \mathrm{C}\right)$ Ringer's solution of the following composition (in mmol/l): $122.5 \mathrm{NaCl}, 5.4 \mathrm{KCl}, 1.2$ $\mathrm{CaCl}_{2}, 0.8 \mathrm{MgCl}_{2}, 10 \mathrm{HEPES}, 5.5$ glucose, $\mathrm{pH}$ 7.4. When indicated the extracellular $\mathrm{K}^{+}$concentration was elevated to $50 \mathrm{mmol} / \mathrm{l}$ - isosmotically replacing $44.6 \mathrm{mmol} / 1 \mathrm{NaCl}$. The mean cellular fluorescence intensities were corrected by background subtraction and measured in $10 \mathrm{~s}$ intervals. $\mathrm{Ca}^{2+}$ measurements were calibrated at the end of each experiment. Maximal and minimal ratios were determined separately for each cell following the application of Ringer's solutions containing ionomycin $(1 \mu \mathrm{M})$ and either $5 \mathrm{mM}$ EGTA or $5 \mathrm{mM} \mathrm{Ca}^{2+}$.

\section{Determination of calpain activity}

To determine calpain activity in single cells the Boc assay was used [55]. Glass bottom dishes (Greiner BioOne, Frickenhausen, Germany) were coated for $30 \mathrm{~min}$ with 1:10 diluted basal membrane-like matrix, before $\sim 2.3$ $\times 10^{4}$ cells were plated in growth medium to attach for 3-4 hours at $37^{\circ} \mathrm{C}$ and $5 \% \mathrm{CO}_{2}, 95 \%$ air. $5 \mathrm{~min}$ prior to the experiment DMEM/F12 medium was replaced with Hepes-buffered Ringer solution. Cells were then either treated in the presence or absence of $50 \mathrm{ng} / \mathrm{ml}$ PDGF with DMSO $(1: 1000)$ or TRAM-34 $(10 \mu \mathrm{mol} / \mathrm{l})$ for 30 min. Thereafter, cells were transferred to the microscope stage (Axiovert 200) and the calpain substrate 7-amino4-chloromethylcoumarin, t-BOC-L-leucyl-L-methionine amide (CMAC, t-BOC-Leu-Met; $10 \mu \mathrm{M}$; Molecular Probes) was added. After $20 \mathrm{~min}$ at $37^{\circ} \mathrm{C}$ fluorescence images were taken using a digital camera (model 9.0, RT-
SE-Spot, Visitron) and the MetaVue software (Visitron). We used the following filter set: excitation $365 / 12 \mathrm{~nm}$, beam splitter $395 \mathrm{~nm}$, emission $397 \mathrm{~nm}$. Image exposure settings were identical within each experiment: $100 \mathrm{msec}$ for CMAC, t-BOC-Leu-Met. Fluorescence intensity was measured over the entire projected cell area and corrected for background fluorescence in ImageJ.

\section{Statistics}

All data are presented as means \pm SEM. Statistically significant differences were determined with paired or unpaired $t$-test or with one-way ANOVA and post hoc Bonferroni test for multiple comparisons as appropriate. For non-parametric comparison of two groups, we applied Wilcoxon-Mann-Whitney-Test.

\section{Abbreviations}

CCL5: C-C motif chemokine ligand $3 ; \mathrm{K}_{\mathrm{Ca}} 3.1: \mathrm{Ca}^{2+}$ activated potassium channel of intermediate conductance; PDGF: platelet-derived growth factor; PSC: pancreatic stellate cell; RANTES: regulated upon activation normal $\mathrm{T}$ cell expressed and secreted; TRAM-34: 1-[(2-chlorophenyl)-di(phenyl)methyl]pyrazole $\left(\mathrm{K}_{\mathrm{Ca}} 3.1\right.$ channel blocker); TRPC1 and TRPC3: transient receptor potential cation channel, subfamily $\mathrm{C}$ (canonical), member 1 and 3; TRPV4: transient receptor potential cation channel, subfamily V (vanailloid), member 4; TRPA1: transient receptor potential cation channel, subfamily A (ankyrin), member 1.

\section{ACKNOWLEDGMENTS}

The help of Monika Rozewitz for evaluating the effect of PDGF on RLT-PSC migration and Elke $\mathrm{Na} 3$ for performing patch clamp experiments is greatly acknowledged. TRAM-34 was a kind gift of Heike Wulff, University of California, Davis, USA. RLT-PSCs were kindly provided by Ralf Jesnowsky, Mannheim, Germany. We wish to thank Peter Ruth, Tübingen, Germany, for providing us with $\mathrm{K}_{\mathrm{Ca}} 3.1^{-/-}$mice and their littermates.

\section{CONFLICTS OF INTEREST}

\section{None.}

\section{FUNDING}

This work was supported by the Marie Curie Initial Training Network IonTraC (FP7-PEOPLE-2011-ITN Grant Agreement No. 289648), Deutsche Krebshilfe (Grant No. 110261), Deutsche Forschungsgemeinschaft, Cells-in-Motion Cluster of Excellence (EXC 1003CiM), University of Münster, Germany, IZKF Münster 
(Bud3/001/16); the Danish Council for Independent Research - Natural Sciences (DFF-4002-00162).

\section{Authors' contributions}

The contribution of the authors is as follows. H.S.: $\mathrm{K}_{\mathrm{Ca}} 3.1$ in RLT-PSC migration and $\left[\mathrm{Ca}^{2+}\right]_{\mathrm{I}}$; B.H.: migration/ chemotaxis of primary PSCs; S.Sch.: $\left[\mathrm{Ca}^{2+}\right]_{\mathrm{i}}$ and migration in siTRPC3 RLT-PSCs; S.S.: immunostaining, siTRPC3; N.N.: measurements of calpain activity; A.Z. and H.K.: expression analysis of TRPC 3 and $\mathrm{K}_{\mathrm{Ca}} 3.1$ channels from microarray analysis; T.B.: patch clamp analysis; I.N.: establishment of PSC primary cultures; A.S.: design of the study and writing the paper.

\section{REFERENCES}

1. Apte MV, Pirola RC, Wilson JS. Pancreatic stellate cells: a starring role in normal and diseased pancreas. Front Physiol. 2012; 3:344.

2. Phillips PA, Yang L, Shulkes A, Vonlaufen A, Poljak A, Bustamante S, Warren A, Xu Z, Guilhaus M, Pirola R, Apte MV, Wilson JS. Pancreatic stellate cells produce acetylcholine and may play a role in pancreatic exocrine secretion. Proc Natl Acad Sci USA. 2010; 107:17397-17402.

3. Mato E, Lucas M, Petriz J, Gomis R, Novials A. Identification of a pancreatic stellate cell population with properties of progenitor cells: new role for stellate cells in the pancreas. Biochem J. 2009; 421:181-191.

4. Bachem MG, Zhou S, Buck K, Schneiderhan W, Siech M. Pancreatic stellate cells-role in pancreas cancer. Langenbecks Arch Surg. 2008; 393:891-900.

5. Andoh A, Takaya H, Saotome T, Shimada M, Hata K, Araki Y, Nakamura F, Shintani Y, Fujiyama Y, Bamba T. Cytokine regulation of chemokine (IL-8, MCP-1, and RANTES) gene expression in human pancreatic periacinar myofibroblasts. Gastroenterology. 2000; 119:211-219.

6. Kalthoff H, Roeder C, Humburg I, Thiele HG, Greten H, Schmiegel W. Modulation of platelet-derived growth factor A- and B-chain/c-sis mRNA by tumor necrosis factor and other agents in adenocarcinoma cells. Oncogene. 1991; 6:1015-1021.

7. Mahadevan D, Von Hoff DD. Tumor-stroma interactions in pancreatic ductal adenocarcinoma. Mol Cancer Ther. 2007; 6:1186-1197.

8. Erkan M, Reiser-Erkan C, Michalski CW, Deucker S, Sauliunaite D, Streit S, Esposito I, Friess H, Kleeff J. Cancer-stellate cell interactions perpetuate the hypoxiafibrosis cycle in pancreatic ductal adenocarcinoma. Neoplasia. 2009; 11:497-508.

9. Winter JM, Brennan MF, Tang LH, D'Angelica MI, Dematteo RP, Fong Y, Klimstra DS, Jarnagin WR, Allen PJ. Survival after resection of pancreatic adenocarcinoma: results from a single institution over three decades. Ann Surg Oncol. 2012; 19:169-175.
10. Carr RM, Fernandez-Zapico ME. Pancreatic cancer microenvironment, to target or not to target? EMBO Mol Med. 2016; 8:80-82.

11. Ozdemir BC, Pentcheva-Hoang T, Carstens JL, Zheng X, Wu CC, Simpson TR, Laklai H, Sugimoto H, Kahlert C, Novitskiy SV, De Jesus-Acosta A, Sharma P, Heidari P, et al. Depletion of carcinoma-associated fibroblasts and fibrosis induces immunosuppression and accelerates pancreas cancer with reduced survival. Cancer Cell. 2014; 25:719-734.

12. Brevet M, Fucks D, Chatelain D, Regimbeau JM, Delcenserie R, Sevestre H, Ouadid-Ahidouch H. Deregulation of 2 potassium channels in pancreas adenocarcinomas: implication of $\mathrm{K}_{\mathrm{V}} 1.3$ gene promoter methylation. Pancreas. 2009; 38:649-654.

13. Gomez-Varela D, Zwick-Wallasch E, Knotgen H, Sanchez A, Hettmann T, Ossipov D, Weseloh R, ContrerasJurado C, Rothe M, Stuhmer W, Pardo LA. Monoclonal antibody blockade of the human Eag1 potassium channel function exerts antitumor activity. Cancer Res. 2007; 67:7343-7349.

14. Herner A, Sauliunaite D, Michalski CW, Erkan M, De Oliveira T, Abiatari I, Kong B, Esposito I, Friess H, Kleeff J. Glutamate increases pancreatic cancer cell invasion and migration via AMPA receptor activation and Kras-MAPK signaling. Int J Cancer. 2011; 129:2349-2359.

15. Rybarczyk P, Gautier M, Hague F, Dhennin-Duthille I, Chatelain D, Kerr-Conte J, Pattou F, Regimbeau JM, Sevestre H, Ouadid-Ahidouch H. Transient receptor potential melastatin-related 7 channel is overexpressed in human pancreatic ductal adenocarcinomas and regulates human pancreatic cancer cell migration. Int J Cancer. 2012; 131:E851-E861.

16. Yee NS, Brown RD, Lee MS, Zhou W, Jensen C, Gerke H, Yee RK. TRPM8 ion channel is aberrantly expressed and required for preventing replicative senescence in pancreatic adenocarcinoma: potential role of TRPM8 as a biomarker and target. Cancer Biol Ther. 2012; 13:592-599.

17. Dozynkiewicz MA, Jamieson NB, Macpherson I, Grindlay J, van den Berghe PV, von Thun A, Morton JP, Gourley C, Timpson P, Nixon C, McKay CJ, Carter R, Strachan D, et al. Rab25 and CLIC3 collaborate to promote integrin recycling from late endosomes/lysosomes and drive cancer progression. Dev Cell. 2012; 22:131-1345.

18. Prevarskaya N, Skryma R, Shuba Y. Ion channels and the hallmarks of cancer. Trends Mol Med. 2010; 16:107-121.

19. Zhang LP, Ma F, Abshire SM, Westlund KN. Prolonged high fat / alcohol exposure increases TRPV4 and its functional responses in pancreatic stellate cells. Am J Physiol Regul Integr Comp Physiol. 2013; 304:R702-R711.

20. Haanes KA, Schwab A, Novak I. The P2X7 receptor supports both life and death in fibrogenic pancreatic stellate cells. PLoS One. 2012; 7:e51164.

21. Paulo JA, Urrutia R, Banks PA, Conwell DL, Steen H. Proteomic analysis of an immortalized mouse pancreatic 
stellate cell line identifies differentially-expressed proteins in activated vs nonproliferating cell states. J Proteome Res. 2011; 10:4835-4844.

22. Fels B, Nielsen N, Schwab A. Role of TRPC1 channels in pressure-mediated activation of murine pancreatic stellate cells. European Biophysical Journal: EBJ. 2016; 45:657-670.

23. Iyer SC, Kannan A, Gopal A, Devaraj N, Halagowder D. Receptor channel TRPC6 orchestrate the activation of human hepatic stellate cell under hypoxia condition. Exp Cell Res. 2015; 336:66-75.

24. Freise C, Heldwein S, Erben U, Hoyer J, Kohler R, Johrens K, Patsenker E, Ruehl M, Seehofer D, Stickel F, Somasundaram R. $\mathrm{K}^{+}$-channel inhibition reduces portal perfusion pressure in fibrotic rats and fibrosis associated characteristics of hepatic stellate cells. Liver Int. 2015; 35:1244-1252.

25. Nielsen N, Lindemann O, Schwab A. TRP channels and STIM/ORAI proteins: Sensors and effectors of cancer and stroma cell migration. Br J Pharmacol. 2014; 171:5524-5540 doi: 10.1111/bph.12721.

26. Schwab A, Wulf A, Schulz C, Kessler W, NechyporukZloy V, Romer M, Reinhardt J, Weinhold D, Dieterich P, Stock C, Hebert SC. Subcellular distribution of calciumsensitive potassium channels (IK1) in migrating cells. J Cell Physiol. 2006; 206:86-94.

27. Schwab A, Fabian A, Hanley PJ, Stock C. Role of ion channels and transporters in cell migration. Physiol Rev. 2012; 92:1865-1913.

28. Dieterich P, Klages R, Preuss R, Schwab A. Anomalous dynamics of cell migration. Proc Natl Acad Sci USA. 2008; 105:459-463.

29. Waschk DE, Fabian A, Budde T, Schwab A. Dual-color quantum dot detection of a heterotetrameric potassium channel $\left(\mathrm{hK}_{\mathrm{Ca}} 3.1\right)$. Am J Physiol Cell Physiol. 2011; 300:C843-C849.

30. Chen YJ, Raman G, Bodendiek S, O'Donnell ME, Wulff H. The $\mathrm{K}_{\mathrm{Ca}} 3.1$ blocker TRAM-34 reduces infarction and neurological deficit in a rat model of ischemia/reperfusion stroke. J Cereb Blood Flow Metab. 2011; 31:2363-2374.

31. Won JH, Zhang Y, Ji B, Logsdon CD, Yule DI. Phenotypic changes in mouse pancreatic stellate cell $\mathrm{Ca}^{2+}$ signaling events following activation in culture and in a disease model of pancreatitis. Mol Biol Cell. 2011; 22:421-436.

32. Kim EY, Alvarez-Baron CP, Dryer SE. Canonical transient receptor potential channel (TRPC) 3 and TRPC6 associate with large-conductance $\mathrm{Ca}^{2+}$-activated $\mathrm{K}^{+}$(BKCa) channels: role in BKCa trafficking to the surface of cultured podocytes. Mol Pharmacol. 2009; 75:466-477.

33. Sancho-Bru P, Bataller R, Colmenero J, Gasull X, Moreno M, Arroyo V, Brenner DA, Gines P. Norepinephrine induces calcium spikes and proinflammatory actions in human hepatic stellate cells. Am J Physiol Gastrointest Liver Physiol. 2006; 291:G877-G884.

34. Kim SY, Cho BH, Kim UH. CD38-mediated $\mathrm{Ca}^{2+}$ signaling contributes to angiotensin II-induced activation of hepatic stellate cells: attenuation of hepatic fibrosis by CD38 ablation. J Biol Chem. 2010; 285:576-582.

35. Cattaruzza F, Johnson C, Leggit A, Grady E, Schenk AK, Cevikbas F, Cedron W, Bondada S, Kirkwood R, Malone B, Steinhoff M, Bunnett N, Kirkwood KS. Transient receptor potential ankyrin 1 mediates chronic pancreatitis pain in mice. Am J Physiol Gastrointest Liver Physiol. 2013; 304:G1002-G1012.

36. Ceppa E, Cattaruzza F, Lyo V, Amadesi S, Pelayo JC, Poole DP, Vaksman N, Liedtke W, Cohen DM, Grady EF, Bunnett NW, Kirkwood KS. Transient receptor potential ion channels V4 and A1 contribute to pancreatitis pain in mice. Am J Physiol Gastrointest Liver Physiol. 2010; 299:G556-G571.

37. Nakamura T, Ito T, Uchida M, Hijioka M, Igarashi H, OonoT, Kato M, Nakamura K, Suzuki K, Jensen RT, Takayanagi R. PSCs and GLP-1R: occurrence in normal pancreas, acute/ chronic pancreatitis and effect of their activation by a GLP1R agonist. Lab Invest. 2014; 94:63-78.

38. Kim MS, Hong JH, Li Q, Shin DM, Abramowitz J, Birnbaumer L, Muallem S. Deletion of TRPC3 in mice reduces store-operated $\mathrm{Ca}^{2+}$ influx and the severity of acute pancreatitis. Gastroenterology. 2009; 137:1509-1517.

39. Gryshchenko O, Gerasimenko JV, Gerasimenko OV, Petersen $\mathrm{OH}$. $\mathrm{Ca}^{2+}$ signals mediated by bradykinin type 2 receptors in normal pancreatic stellate cells can be inhibited by specific $\mathrm{Ca}^{2+}$ channel blockade. J Physiol. 2016; 594:281-293.

40. Schuppan D, Kim YO. Evolving therapies for liver fibrosis. J Clin Invest. 2013; 123:1887-1901.

41. Heinemann V, Reni M, Ychou M, Richel DJ, Macarulla T, Ducreux M. Tumour-stroma interactions in pancreatic ductal adenocarcinoma: rationale and current evidence for new therapeutic strategies. Cancer Treat Rev. 2014; 40:118-128.

42. Stroka KM, Jiang H, Chen SH, Tong Z, Wirtz D, Sun SX, Konstantopoulos K. Water permeation drives tumor cell migration in confined microenvironments. Cell. 2014; 157:611-823.

43. Watkins S, Sontheimer H. Hydrodynamic cellular volume changes enable glioma cell invasion. J Neurosci. 2011; 31:17250-17259.

44. Happel P, Moller K, Schwering NK, Dietzel ID. Migrating oligodendrocyte progenitor cells swell prior to soma dislocation. Sci Rep. 2013; 3:1806.

45. Guinamard R, Salle L, Simard C. The non-selective monovalent cationic channels TRPM4 and TRPM5. Adv Exp Med Biol. 2011; 704:147-171.

46. Kunzelmann K. TMEM16, LRRC8A, bestrophin: chloride channels controlled by $\mathrm{Ca}^{2+}$ and cell volume. Trends Biochem Sci. 2015; 40:535-543.

47. Svensson L, McDowall A, Giles KM, Stanley P, Feske S, Hogg N. Calpain 2 controls turnover of LFA-1 adhesions on migrating T lymphocytes. PLoS One. 2010; 5:e15090.

48. Lokuta MA, Nuzzi PA, Huttenlocher A. Calpain regulates neutrophil chemotaxis. Proc Natl Acad Sci USA. 2003; 100:4006-4011. 
49. Senadheera S, Kim Y, Grayson TH, Toemoe S, Kochukov MY, Abramowitz J, Housley GD, Bertrand RL, Chadha PS, Bertrand PP, Murphy TV, Tare M, Birnbaumer L, et al. Transient receptor potential canonical type 3 channels facilitate endothelium-derived hyperpolarization-mediated resistance artery vasodilator activity. Cardiovasc Res. 2012; 95:439-447.

50. Cuddapah VA, Turner KL, Sontheimer H. Calcium entry via TRPC1 channels activates chloride currents in human glioma cells. Cell Calcium. 2013; 53:187-194.

51. Jesnowski R, Furst D, Ringel J, Chen Y, Schrodel A, Kleeff J, Kolb A, Schareck WD, Lohr M. Immortalization of pancreatic stellate cells as an in vitro model of pancreatic fibrosis: deactivation is induced by matrigel and $\mathrm{N}$-acetylcysteine. Lab Invest. 2005; 85:1276-1291.

52. Antigny F, Jousset H, Konig S, Frieden M. Thapsigargin activates $\mathrm{Ca}^{2+}$ entry both by store-dependent, STIM1/ Orail-mediated, and store-independent, TRPC3/PLC/ PKC-mediated pathways in human endothelial cells. Cell Calcium. 2011; 49:115-127.

53. Schwab A, Nechyporuk-Zloy V, Gassner B, Schulz C, Kessler W, Mally S, Romer M, Stock C. Dynamic redistribution of calcium sensitive potassium channels $\left(\mathrm{hK}_{\mathrm{Ca}} 3.1\right)$ in migrating cells. J Cell Physiol. 2012; 227:686-696.

54. Fabian A, Bertrand J, Lindemann O, Pap T, Schwab A. Transient receptor potential canonical channel 1 impacts on mechanosignaling during cell migration. Pflügers Arch. 2012; 464:623-630.

55. Rosser BG, Powers SP, Gores GJ. Calpain activity increases in hepatocytes following addition of ATP. Demonstration by a novel fluorescent approach. J Biol Chem. 1993; 268:23593-23600.

56. Grützmann R, Pilarsky C, Ammerpohl O, Luttges J, Bohme A, Sipos B, Foerder M, Alldinger I, Jahnke B, Schackert HK, Kalthoff H, Kremer B, Kloppel G, et al. Gene expression profiling of microdissected pancreatic ductal carcinomas using high-density DNA microarrays. Neoplasia. 2004; 6:611-622.

57. Pilarsky C, Ammerpohl O, Sipos B, Dahl E, Hartmann A, Wellmann A, Braunschweig T, Lohr M, Jesenofsky R, Friess H, Wente MN, Kristiansen G, Jahnke B, et al. Activation of Wnt signalling in stroma from pancreatic cancer identified by gene expression profiling. J Cell Mol Med. 2008; 12:2823-2835.

58. Ammerpohl O, Trauzold A, Schniewind B, Griep U, Pilarsky C, Grutzmann R, Saeger HD, Janssen O, Sipos B, Kloppel G, Kalthoff H. Complementary effects of HDAC inhibitor 4-PB on gap junction communication and cellular export mechanisms support restoration of chemosensitivity of PDAC cells. Br J Cancer. 2007; 96:73-81. 